\title{
The Cold War and the Welfare State in Western Europe
}

\section{Klaus Petersen, Michele Mioni, and Herbert Obinger}

\section{Introduction}

The Cold War and the growth of the welfare state constitute two major frameworks for understanding politics and society in post-1945 Western Europe. That war and conflict had an impact on the development of modern welfare states is well established (Obinger et al. 2018). So far, less attention has been paid to the linkages between the Cold War and social policy reform during the so-called Golden Age of the welfare state (ca. 1945-1975). In this chapter, we ask the simple question: How did the Cold War influence the development of welfare states in selected Western European countries in the first decades after 1945?

\footnotetext{
K. Petersen $(\bowtie)$

University of Southern Denmark and Danish Institute Advanced Studies (DIAS), Odense, Denmark

e-mail: klaus.petersen@sdu.dk

M. Mioni $\bullet$ H. Obinger

University of Bremen, Bremen, Germany

e-mail:michele.mioni@uni-bremen.de; herbert.obinger@uni-bremen.de

(C) The Author(s) 2022 
However, simple questions rarely have simple answers. The Cold War was primarily a battle for the "hearts and minds" of the people (Westad 2017). The Socialist Eastern Bloc led by the Soviet Union competed with capitalist Western democracies (Pax Americana). Key aspects of this systemic competition were social reform, economic well-being and the development of advanced welfare states offering a brighter and more secure future for their populations. Systemic competition also positively influenced patterns of social spending (Obinger and Schmitt 2011).

In contemporary debates, the welfare state was seen as "a compromise between the two extremes of Communism on the one hand, and unbridled Individualism on the other" (Hobman 1953, 1). However, this compromise could take different forms and shapes. The Cold War influenced the development of the welfare state in multiple ways as national contexts (political, social and institutional) varied. Due to the limited space of this essay, we focus on two mechanisms linking the Cold War and the Western welfare state (see Petersen 2013):

First, social policies were important for securing mass loyalty and as an anti-communist strategy in Western Europe. Developing social security programmes offered (market-based) alternative to communism and secured the loyalty of the working class. Social reforms worked as a bulwark against communism, hand-in-hand with tougher anti-communist measures. Second, the Cold War heavily impacted political coalitionbuilding in Western countries. We see the exclusion of Communists from the decision-making process, Social Democrats moderating their ideological positions, and Conservatives, Liberals and Reformist Socialists uniting against the common enemy of communism. There are further impacts of the Cold War, which cannot be discussed in detail, however. For example, the Cold War altered international alliances and networks as well as the routes for social policy diffusion. New transnational actors emerged (International Monetary Fund [IMF], Organisation for Economic Co-operation and Development [OECD] and later the European Union [EU]), and the influence of US social sciences on European experts was significantly facilitated by channels such as the Fulbright Program, the European Recovery Program (ERP; Marshall Aid), and the International Labour Organization (ILO). 
In the following sections, we present a condensed overview of how these mechanisms played out in countries with different welfare state types: the Nordic countries, Italy and divided Germany.

\section{The Nordic Countries}

The development of the Nordic welfare states was affected by the Cold War in multiple ways. This is hardly surprising, as the major reforms and expansion of the Nordic welfare states coincided chronologically with the Cold War. The historical roots of the Nordic welfare model predate the Cold War, but it was the rivalry between the two superpowers, from the late 1940s to the 1960s, that lay the socio-political framework for the post-war expansion of the welfare state. Arguably, the Cold War-welfare state nexus cannot solely explain the routes and timing of Nordic social policy reforms, but there are clear links between ideological patterns, political competition and security considerations.

As World War II ended and the Cold War dawned, the Nordic countries found themselves in a new situation. As established liberal democracies and market economies, they ideologically oriented towards the US-dominated West, while the region was geographically close to the Soviet Union and consequently of great geostrategic importance. However, plans for a Scandinavian defence union very soon faltered and the Nordic countries chose different national security strategies. Sweden remained formally neutral backed by a strong military defence. Finland also opted for neutrality but the proximity to Russia meant that Finnish politics continuously had to maintain a positive relation and dialogue with the Soviet superpower. Denmark, on the other hand, together with Norway, joined the US-led North Atlantic Treaty Organization (NATO) alliance in 1949.

Even with this variation in national security strategies, the development of the national welfare state systems in the Nordic region followed quite similar paths (Christiansen et al. 2006), which was facilitated by close social policy cooperation in the region based on the idea of a Nordic "middle way" between US-style capitalism and socialism. The successful development of comprehensive welfare states combined free market 
capitalism with state regulation and widespread public social security, which allowed the Nordic countries to take a special position within the Western bloc. The progressive (Social Democratic) market economy brand attracted international attention as a way of transcending the black and white logic of the Cold War. According to the book Freedom and Welfare (Nelson 1953), published jointly by the Nordic ministries of social affairs, the Nordic societies were successful precisely because they combined freedom with welfare-and Nordic ministers did not shy away from portraying this as a model for the rest of the world. Consequently, the Nordic countries successfully entered the systemic competition of the Cold War by defining a "middle way" that legitimised the development of comprehensive welfare states.

The "middle way" approach also served its purpose in domestic politics. Systemic competition not only played out on the international scene between rivalling nations, but also on the domestic level. In all Nordic countries, we find heated conflicts between Social Democrats and Communists over the hearts and minds of the working class. Social reforms were at the forefront of this battle for the loyalty of the masses in many ways.

First, social expenditure rose dramatically in post-war Nordic societies, triggering a trade-off between military and social spending. Neutral Sweden came out of World War II with a strong economy and turned military production into a profitable export venture during the Cold War. Denmark, on the other hand, found itself under dual pressure. The US and NATO were demanding higher military spending at the same time as Social Democratic governments were planning to expand the welfare state. The Danish Communists actively used this guns-butter tradeoff, advocating that NATO was not only a threat to world peace but also to the social welfare of the Danes. In 1952, the then Minister of Defence, Poul Sørensen (from the Conservative Party) spent a full radio address downplaying the conflict between social security and NATO membership (Petersen 2013, 229-30). From the late 1950s onwards, when the Nordic countries entered a period with strong economic growth, the guns-butter trade-off became less important.

Second, social reforms were actively used in Social Democratic propaganda against the Communists (Petersen 2013). The combination of 
growing affluence and increasing social security meant that Nordic societies compared favourably to socialist societies east of the Iron Curtain. Such systemic competition on the domestic level played a key role for the success of Nordic Social Democratic labour movements vis-à-vis their Communist opponents in the quest for loyalty of the national workers.

Third, the "middle way" also served as a platform for political alliances between Social Democrats and the Centre Right. Emphasising the divides between the revolutionary and reformist left allowed Social Democracy to become the main representative of the establishment while also gradually making the Centre Right accept the potential welfare reforms as a bulwark against communism. Whereas this way proved successful in excluding Communists politically through social reforms in Denmark, Sweden and Norway, the Finnish case was far more complex (RainioNiemi 2014). Finnish Communists mobilised an electoral base of around twenty percent. Parliamentary strength in combination with support from neighbouring USSR gave the Communists a more prominent role in Finnish politics. Also, Finland was the latecomer among the Nordic welfare states, and the so-called "popular front" government of 1966-1970, which included Social Democrats, the Agrarian Centre Party and the Communists, is often hailed in popular historiography for the breakthrough of the Finnish welfare state (Kettunen 2018).

In short, the welfare state was a successful anti-communist strategy which secured the loyalty of the masses to the Nordic welfare state. This played out on the domestic level as well as the trans-Nordic level, which is rooted in the Nordic region's strong historical tradition for cooperation. Even though the Cold War set limits to cooperation due to the different national geostrategic positions, we find increased social policy cooperation driven not least by the strong Social Democratic labour movements. This also included anti-communist cooperation-such as the exchange of information and propaganda, cooperation with intelligence services, coordination-which reinforced the strategic choice of a soft version of anti-communism using social reforms and social progress as the main bulwark against local communism. Countering a genuine pressure for tougher repercussions against Communists from US actors (at embassies and international organisations), Scandinavian Social 
Democrats and trade unionists maintained their preference for a soft anti-communism as the most efficient bulwark against communism (Petersen and Schmidt 2001; Misgeld 1997).

\section{Italy}

In Italy, both mechanisms discussed in this chapter affected the evolution of the welfare state and its political use during the Cold War. The 1948 general elections marked the end of the National Unity Government and the beginning of almost fifty years of uninterrupted government by the Christian Democracy (DC), while the Italian Communist Party (Partito Comunista Italiano [PCI]) took the lead of the left spectrum. The year before, the third Italian party (Partito Socialista Italiano di Unita Proletaria [PSIUP]) split on the issue of international alliances into the anticommunist Social Democratic Party (Partito Socialista Democratico Italiano $[\mathrm{PSDI}])$, which would become the most loyal ally of the DC for decades, and the left-wing PSI-Partito Socialista Italiano. The divide in international positioning vis-à-vis the two bloc's cleavages was mirrored in the domestic socio-economic debates and conflicts, at least during the early Cold War.

Until the early 1970s, the welfare state was a bone of contention between the government bloc, led by the DC, and the Communists. In 1947, Ludovico D'Aragona, a former anti-communist trade unionist who joined the PSDI and the centrist government alliance, chaired a commission that was appointed to prepare a comprehensive reform of social security. In the related debates, social security was fiercely contested between anti-communist and pro-Soviet parties. While the left-wing faction within the DC and the PSDI supported the social security reforms, the Communists criticised them because they would weaken the class struggle and divide the working class (Mioni 2016).

At the end of the 1940s, DC-led governments passed important social reforms on housing and land. A prospective reform of social insurance targeting salaried and industrial workers was not enforced but played an important role in the strategy of the DC (in charge of the Minister of 
Social Security) to "liberate" the workers from their links with the communist movement through social welfare (Pavan 2015). The DC's interclass, corporatist social views were reflected in a strategy that tried to integrate rural and industrial working classes and soften class antagonism through social reforms.

Against the backdrop of a still semi-industrial country, land reform and the development of public works and infrastructure were motivated by anti-communist goals, especially in Southern Italy. This strategy was influenced by the US plans for the economic recovery of Europe including the Marshall Plan (Bernardi 2006). The idea was to disconnect the rural masses from agitation by social-communist organisations by promoting economic growth. The reform served to hamper the workers' quests for land collectivisation, and at the same time aimed to create a new class of small landowners, loyal to the governing parties. Welfare benefits were used by the government parties to attract votes, strengthen political loyalty and to undercut popular support for the Communists. This political dynamic shaped structures and practices of the Italian welfare state in the longer run (Ferrera 1996; Manow 2009).

In the 1950s, the Socialists embarked on a revisionist path with regard to the scope and goals of social policy. The PSI revoked its alliance with the PCI after 1956. This shift opened up the opportunity for the Socialists' co-participation in government with the DC in 1963, which was based on a programme that also included a "welfare state from the cradle to the grave" (Nenni 1964). By that year, Italy had accomplished its "economic miracle" and became a fully fledged industrial country. This second phase of reforms was primarily confronted with increasingly conflictual industrial relations. The government's reform programme featured the extension of industrial injury and sickness benefits, and the introduction of social pensions. In the same period, the discussions on the universalist national health service was initiated. Such reform came into being in 1978. A major reform of the centre left government was the Workers' Statute, passed in 1970. The PSI strongly supported this legislation, which was fiercely opposed by the Communists. The statute resulted from the collaboration between Catholics and Socialists and aimed to regulate industrial strife in a period of harsh radicalisation that developed 
independently from the PCI itself. After 1970, social and political dynamics in Italy changed. However, further developments crystallised the use of welfare for political struggles.

\section{Divided Germany}

System competition in the early Cold War period was particularly intense in divided Germany. Against the backdrop of a war-torn economy and post-war destitution, the sheer existence of a socialist alternative next door was challenging for West Germany (Federal Republic of Germany [FRG]), not least because the German Democratic Republic (GDR) aggressively showcased socialism as a role model for Germany as a whole. Likewise, the FRG was an important reference point for the GDR's communist regime. In the formative years, the GDR prioritised economic development and industrialisation with a view to demonstrating the superiority of socialism vis-à-vis Western capitalism. At its fifth party conference in 1958, the Communist Party even heralded that socialism would economically come out as the winner of regime competition. In terms of social affairs, the communist regime praised the right to work ${ }^{1}$ and other achievements of socialism, classified unemployment as a scourge of capitalism and blamed the Western welfare state for being a "sickbay of capitalism" (Hockerts 1994).

The FRG's counter-model was the Soziale Marktwirtschaft, which was seen as a liberal and superior alternative to collectivism. It was developed by economist Müller-Armack in the late 1940s who saw the Soziale Marktwirtschaft as a third way between unfettered capitalism and socialist collectivism. Influenced by Christian social ethics, the concept combined ordo-liberal ideas in economic policy with welfare state policies designed to cushion the negative consequences of capitalism. At the same time, when the communist leaders in East Berlin announced the victory of socialism, Ludwig Erhard, Minister of Economic Affairs and one of the fathers of the Soziale Marktwirtschaft, promised that it would generate "prosperity for all" (Erhard 1957). In contrast to the audacious

${ }^{1}$ Which in fact was an obligation to work. 
announcements of the communist regime to outpace West Germany in terms of economic performance, this promise of a "social capitalism" was real. Accelerated by economic reconstruction and aid from the ERP, economic growth, wages and consumption significantly increased in the 1950s, while unemployment virtually disappeared. In addition, the West German Wirtschaftswunder laid the basis for a massive welfare state expansion. While social policy in the immediate post-war period had focused on provisions for war victims and refugees, Chancellor Adenauer announced a comprehensive welfare reform in 1953, which was also motivated by system competition. Specifically, he argued that West Germany must remain attractive to people from the GDR (Kleßmann 1991, 251) and had to be immunised against communist propaganda (Schmidt 2005, 83). Social Democrat Ludwig Preller argued in the same year that "especially in the Cold War it is welfare state generosity that marshals the biggest battalions". In fact, Adenauer's pension reform of 1957 massively increased pension generosity and tied pensions to the dynamics of gross wages. Welfare state expansion in West Germany thus put the GDR on the spot (Hockerts 1994, 797). However, for economic reasons the regime in East Berlin was unable to compete with West Germany, where the economic miracle also facilitated welfare state expansion in other areas (e.g. the overhaul of social assistance in 1961). In consequence, the GDR was not only outdistanced in terms of economic performance but also in social policy, particularly in the field of old-age pensions, which were the Achilles heel of the socialist welfare model (Schmidt 2001).

The Cold War also shaped party politics and ideological realignment. The Adenauer government accelerated Western integration and embarked on a harsh anti-communist course. The Hallstein Doctrine and NATO membership (1955), which were formative for international affairs, were mirrored in domestic politics by the ban of the Communist Party (Kommunistische Partei Deutschlands [KPD]) in 1956, which had gained 5.7 percent of the national vote in 1949. The Cold War also moderated the Social Democrats, who accepted the market economy and national defence in their new political programme, which was named after the city of Bad Godesberg and passed in 1959. Irrespective of ongoing conflicts with the Christian Democrats, this policy shift facilitated cooperation 
between the largest political camps, which, however, were also required to cooperate due to the institutional checks and balances enshrined in the Basic Law. Electoral competition between two pro-welfare-oriented parties and the informal grand coalition of Christian and Social Democrats were, along with the Wirtschaftswunder, the key driving forces of welfare state expansion in the FRG. In consequence, both the Western living standard and the Western welfare state were increasingly out of reach for the GDR from the 1960s onwards.

In retrospect, system competition had a greater impact on the GDR and its socialist welfare system. Already in the GDR's formative years, almost three million people left the country. "Voting with their feet" was brutally stopped with the building of the Berlin Wall in 1961. However, mounting repression reinforced the legitimacy problems of the communist regime (Hockerts 2009). In an attempt to generate mass compliance and pushed by the Soviet Union, the Honecker government considerably expanded the socialist welfare state in the 1970s and enhanced the regime's consumer orientation under the slogan "unity of social and economic policy". However, all those efforts imposed a heavy burden on the command economy and eventually contributed to the breakdown of the regime in 1989 (Hockerts 2009; Schmidt 2001).

\section{Conclusion}

In this chapter, we offer an overview on the linkages between the Cold War and the post-1945 development of welfare states. The idea of such links is far from new. As early as 1946, influential pro-Soviet British historian E. H. Carr argued that Soviet Russia prompted the rejuvenation of Western democracies through economic planning and the welfare state (Carr 1946). In our chapter, we especially emphasise the importance of two social and political mechanisms. First, social policies were important for securing mass loyalty and as an anti-communist strategy in Western Europe. Second, the Cold War strongly impacted political coalitionbuilding in Western countries. We demonstrate the importance of the two sets of mechanisms through case studies representing three different types of welfare states: the Nordic Countries, Italy and divided Germany. 
Notably, the existence of these mechanisms was also recognised by contemporary academic observers. International relations scholar Klaus Knorr argued in an article from 1951 that "it is plausible that the democratic welfare state is the most constructive defense of the free world against Communist expansion, for it offers to many societies, rightly or wrongly dissatisfied with the free-enterprise economy, an alternative to the attractions of Communism" (Knorr 1951). The confrontation with communism, indeed, affected both socio-economic agendas in the West and the formation of political coalitions that eventually shaped welfare states. The domestic dynamics were interconnected with the international context, which altered international alliances and networks as well as the routes for social policy diffusion.

Acknowledgements This chapter is a product of the research conducted in the Collaborative Research Center "Global Dynamics of Social Policy" at the University of Bremen. The centre is funded by the Deutsche Forschungsgemeinschaft (DFG, German Research Foundation)—project number 374666841-SFB 1342.

\section{References}

Bernardi, Emanuele. 2006. La Riforma Agraria in Italia e gli Stati Uniti. Guerra Fredda, Piano Marshall e Interventi per il Mezzogiorno Negli Anni del Centrismo Degasperiano. Bologna: Il Mulino.

Carr, Edward Hallett. 2006 (1946). The Soviet Impact on the Western World. New York: Macmillan

Christiansen, Niels Finn, Klaus Petersen, Nils Edling, and Per Haave, eds. 2006. The Nordic Model of Welfare - A Historical Reappraisal. Copenhagen: Museum Tusculanum.

Erhard, Ludwig. 1957. Wohlstand für Alle. Düsseldorf: Econ.

Ferrera, Maurizio. 1996. The 'Southern Model' of Welfare in Social Europe. Journal of European Social Policy 6 (1): 17-37.

Hobman, Daisy L. 1953. The Welfare State. London: John Murray.

Hockerts, Hans Günter. 1994. Soziale Errungenschaften? Zum Sozialpolitischen Legitimitätsanspruch der Zweiten Deutschen Diktatur. In Von der Arbeiterbewegung zum modernen Sozialstaat, ed. Jürgen Kocka, Hans Jürgen Puhle, and Klaus Tenfelde, 790-804. München: Saur. 
- 2009. West und Ost_-Vergleich der Sozialpolitik in den Beiden Deutschen Staaten. Zeitschrift für Sozialreform 55 (1): 41-56.

Kettunen, Pauli. 2018. Wars, Nation, and the Welfare State in Finland. In Warfare and Welfare. Military Conflict and Welfare State Development in Western Countries, ed. Herbert Obinger, Klaus Petersen, and Peter Starke, 260-289. Oxford: Oxford University Press.

Kleßmann, Christoph. 1991. Die doppelte Staatsgründung. Deutsche Geschichte 1945-1955. Bonn: Bundeszentrale für politische Bildung.

Knorr, Klaus. 1951. The European Welfare State in the Atlantic System. World Politics 3 (4): 417-449.

Manow, Philip. 2009. Electoral Rules, Class Coalitions and Welfare State Regimes, or How to Explain Esping-Andersen with Stein Rokkan. SocioEconomic Review 7 (1): 101-121.

Mioni, Michele. 2016. The Attlee Government and Welfare State Reforms in Post-war Italian Socialism (1945-51): Between Universalism and Class Policies. Labor History 57 (2): 277-297.

Misgeld, Klaus. 1997. Den Fackliga Europavägen. LO, det Internationella Samarbetet och Europas Enande. Stockholm: Arena.

Nelson, Georg. 1953. Freedom and Welfare. Social Patterns in Northern Europe. Copenhagen: Gad.

Nenni, Pietro. 1964. Perché i Socialisti nel Governo. Discorso Pronunciato Dall'on. Pietro Nenni al Teatro Adriano di Roma il 29 Dicembre 1963. Roma: PSI.

Obinger, Herbert, and Carina Schmitt. 2011. Guns and Butter? Regime Competition and the Welfare State during the Cold War. World Politics 63 (2): 246-270.

Obinger, Herbert, Klaus Petersen, and Peter Starke, eds. 2018. Warfare and Welfare. Military Conflict and Welfare States Development in Western Countries. Oxford: Oxford University Press.

Pavan, Ilaria. 2015. Un Progetto "Clandestino" di Riforma. Fanfani e la Previdenza Sociale. Contemporanea 18 (1): 91-109.

Petersen, Klaus. 2013. The Early Cold War and the Western Welfare State. Journal of International and Comparative Social Policy 29 (3): 226-240.

Petersen, Klaus, and Regin Schmidt. 2001. Gemensam Nordisk Front. De Nordiske Socialdemokratiske Arbejderbevægelser og deres AntiKommunistiske Samarbejde under den Kolde Krig. Arbetarhistoria 4: 42-46. Rainio-Niemi, Johanna. 2014. The Ideological Cold War: The Politics of Neutrality in Austria and Finland. London: Routledge. 
Schmidt, Manfred G. 2001. Grundlagen der Sozialpolitik in der Deutschen Demokratischen Republik. In Geschichte der Sozialpolitik in Deutschland seit 1945, ed. Bundesministerium für Arbeit und Sozialordnung und Bundesarchiv, 689-798. Baden-Baden: Nomos. . 2005. Sozialpolitik in Deutschland. Wiesbaden: VS.

Westad, Odd Arne. 2017. The Cold War. A World History. New York: Basic Books.

Open Access This chapter is licensed under the terms of the Creative Commons Attribution 4.0 International License (http://creativecommons.org/licenses/ by/4.0/), which permits use, sharing, adaptation, distribution and reproduction in any medium or format, as long as you give appropriate credit to the original author(s) and the source, provide a link to the Creative Commons licence and indicate if changes were made.

The images or other third party material in this chapter are included in the chapter's Creative Commons licence, unless indicated otherwise in a credit line to the material. If material is not included in the chapter's Creative Commons licence and your intended use is not permitted by statutory regulation or exceeds the permitted use, you will need to obtain permission directly from the copyright holder.

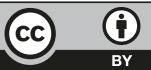

